\title{
IRREGULAR WARFARE IN AFRICAN CONFLICTS
}

\author{
Rialize Ferreira \\ Dept of Sociology, University of South Africa
}

\begin{abstract}
Irregular wars have erupted in African states since colonial independence from Western European countries in the 1960s. The end of the Cold War in 1989 and the changing nature of international politics did not bring about political stability in African states either. These intrastate wars were by-products of historic disputes kept hidden during the Cold War. When the ideological confrontation ended, they surfaced again. Intrastate wars and irregular warfare are not new phenomena on the African continent and led to the collapse of state institutions in countries such as Liberia, Somalia, Sierra Leone, the Democratic Republic of Congo (DRC), Uganda, Sudan and Burundi. Rather than addressing African animosities, conflict continues unabated.
\end{abstract}

The article aims to investigate why irregular (or asymmetric) warfare is utilised in African conflicts where rebel and ethnic groups retain residual military capacity to deploy against weak central governments if their socio-economic demands are not met in the emerging states. The article combines "grievance" and "greed" models to explain the motivations for conflict, while the conceptualisation and utilisation of asymmetric warfare approaches in the African context of irregular war are questioned. Democratic values such as freedom, justice, equality and human dignity are lacking in conflict-ridden societies where unequal forces compete for political and economic control or control over scarce resources. Peacekeeping operations cannot succeed unless the basis for equitable participation in, and the sharing of wealth and power is established in African societies.

\section{Introduction}

It is commonly accepted that an increase in intra-state wars has occurred since the demise of the Cold War in the early 1990s, especially in Africa (Jackson 2007:6). Seemingly Africa is more prone to conflict than other countries as warring nations and factions utilise unconventional, asymmetric warfare to wage and prolong 
conflicts. The historical background of Africa, with its endless wars and extreme poverty creating disorder and instability, affects the progress of democracy. Government forces have been confronted with an enemy or belligerents making use of asymmetric or irregular warfare with a specific outcome in mind, usually to overthrow the government, which they consider as illegitimate. In Africa, the postcolonial period was characterised by different kinds of regimes, ranging from oneparty states to several military regimes frequently governed by ruthless dictators. The historical record of misbehaviour by the state in Africa and of African state's non-compliance with democratic governance as understood by international norms is well known. Until recently, democratically elected governments have been the exception rather than the rule in Africa (Filatova 2000:13).

The underlying historical causes for conflict can be attributed to domestic grievances or circumstances that may prompt irregular warfare. According to Botha (2007:4-5), causes based on domestic grievances may be:

- Closed political systems where democratic transition has failed and restrictions on human rights deprive people of the opportunity to elect a government democratically. Non-state organisations and rebels do not recognise their governments as legitimate (Botha 2007:4).

- Weak and failed African states providing favourable conditions for warring factions to plan, train and launch attacks on government and the local population. The absence of local authority can bring about the growth of safe havens for powerful non-state elements, such as organised crime, human and drug traffickers, and violent extremists. As a result of these fertile circumstances, irregular warfare can be expected to grow and develop into widespread conflicts (Plant 2008:7).

- Control over territories associated with border control: Weak states do not have the human and technological resources and capacity to monitor borders, which then become open and permeable.

- Ethnic motivations where heterogeneous groups, such as the Tutsi and the Hutu of Rwanda, clash over superiority and self-determination and the current government does not adequately represent the specific ethnic group. Feelings of marginalisation led to conflicts as well as genocide in Rwanda in 1994.

- Conflict over natural resources, e.g. in the DRC, Angola, Sudan and Liberia, which causes instability. Minerals such as diamonds, oil and uranium, as well as hardwood are sometimes used as profitable "grey trade" to prolong the conflict unnecessarily. 
- $\quad$ Religion used as a political tool for in mobilising irregular warfare. This extends over national borders and rallies support, e.g. in Sudan and Somalia, where Muslims and Christians are involved in conflict. In combination with poverty, marginalisation and political ideologies, this is an important motivation for irregular or asymmetric warfare.

- Economic circumstances where the local population is unemployed and extremely poor. Sometimes the population is involved in smuggling and "grey trade" to sustain themselves and so prolong the conflict. Widespread conflict creates a breeding ground for alienation. In other cases, prolonging conflict holds benefits for social groups or segments of society (Botha 2007:5).

These grievance-driven causes of conflicts in Africa need to be addressed, in order to understand the reasons for protracted unconventional and irregular warfare on the continent. Collier and Hoeffler (2002:1) call these causes "motivations" for civil war, because they are of the opinion that, although popular perceptions of grievances as motivations for war do exist, these are not in fact the main motivations.

According to these authors, greed outperforms grievance as a motivation for civil war, because the factors determining the financial and military viability of civil war are more important than grievances. To maintain a rebel force, rebels have to be paid and military equipment needs to be purchased. Two contrasting models, the grievance and greed models, were constructed by Collier and Hoeffler (2002:1) to explain the difference in motivations. The grievance model refers to inequality, political oppression, ethnic and religious motivations for conflict, and it corresponds with the domestic grievances cited by Botha (2007:5), while the greed model refers to the sources of finance to maintain the civil war. Collier (in Berdal 2005:1) holds that the key to understanding why such wars erupt lies in greed and the quest for loot by rebel actors. African intrastate wars are mostly driven by economic (greed) motivations in mineral-rich countries; conflict over valuable scarce resources thus. Income from natural resources is an important source to finance rebel movements, while resource-rich countries are at greater risk of conflict (Collier \& Hoeffler 2002:1). African wars usually focus on globally traded commodities, such as diamonds, oil and gun smuggling over open or permeable borders. Economic activities such as these in the DRC spilled over into Sudan, Uganda, Rwanda and Burundi. Border regions provide havens for insurgents, gangs and smugglers in the sense that these regions provide escape routes or exit strategies for armed groups, which are beyond the reach of conventional security forces (Jackson 2007:7). In regions such as these, democratic principles are not practised and belligerents use 
tactics of asymmetric warfare as a method of survival, as well as to prolong warfare. One can expect that future conflict in Africa will be most likely irregular and unconventional.

Collier and Hoeffler (2002:1) suggest that, despite the low motivational explanation of the grievance model, it is better to combine both models to ensure good analysis of motivations for the occurrence of civil wars, which in the author's view will reflect strong elements of irregular warfare. While the grievance and greed models are open to criticism it is argued here that deploying both provides for a fuller picture. For this reason, a combination of both models will be applied here.

\section{Research methodology and theoretical framework}

For this article, a qualitative documentary study based on content analysis of secondary sources is used. Relevant conceptual models of grievance and greed are applied to explain African civil wars. Underlying the methodology is a conflict perspective associated with post-colonial thinking, emphasising the social, political and economic inequalities of populations in post-colonial Africa. This historical era was characterised by the dissolution of European empires and former colonised countries gaining for themselves the status of self-governing nation-states.

The aim of this article is:

- to conceptualise irregular warfare, with special application to Africa, since some elements of Western thinking related to the utility of high technology ensuring low casualties (especially in the contemporary US thought) does not necessarily apply to African "asymmetric", intrastate wars because strategies differ (cf. Buffaloe 2006:17; Grange 2000:2);

- to explore the underlying historical causes of the grievance and greed model for intrastate conflict that promotes irregular, asymmetric warfare in Liberia, Sierra Leone, the DRC, Rwanda, Burundi, Somalia and Darfur and Sudan;

- to correlate the different intrastate conflicts with the causes and motivations determined by the grievance and greed model in African countries, promoting the utilisation of asymmetric warfare; and

- to explore the utility of asymmetric warfare as a concept in order to understand contemporary, irregular wars in African countries.

Although a definite, purposeful definition of asymmetric warfare is difficult to pin down, the study explores the different viewpoints regarding asymmetric warfare. To elaborate on and explain the first aim of the article, the customary thinking about 
asymmetric warfare in Western countries (especially the US) does not always correspond with conflict in Africa, where wars are intrastate and low-tech guerrilla strategies are mostly utilised. These strategies - and tools - differ from Western strategies which utilises expensive technologically advanced precision weaponry against opposing forces. In African conflicts, irregular warfare is regarded as small wars with guerrilla fighters and limited resources suited to the operational environment of intrastate or bush wars. The concepts unconventional, irregular and asymmetric warfare will be used interchangeably throughout this article, while the author prefers the term irregular war.

\section{Irregular or asymmetric warfare? A closer look at concepts}

The origin of the term "asymmetric" dates back to a 1975 article in World Politics by Andrew J.R. Mack in which it refers to as "a significant disparity in power between opposing actors in conflict". "Power" here referred to material power, such as a large army, sophisticated weapons and an advanced economy, such as that of the US. This explanation was largely ignored until the end of the Cold War when the nature of conflict changed. New research regarding the phenomenon during the late 1990s was conducted. David L. Grange by 2000 referred to asymmetric warfare "as conflict deviating from the norm, or an indirect approach to affect a counterbalance of force", since forces seek to negate or avoid the strengths of another, while employing their own strength against the other's weakness. According to Grange (2000:1), "asymmetric warfare is best understood as a strategy, a tactic, or a method of warfare and conflict". The definition of the term remained complicated because the academic and military communities used it in different ways. It was closely associated with a conventional imbalance inducing potential enemies to wage asymmetric or irregular warfare (Bowie, Haffa \& Mullins 2003:130). This resembled, inter alia, guerrilla warfare, insurgency, terrorism, counterinsurgency and counterterrorism. Some in military circles used the term to refer to the indirect nature of strategies adopted by many weak non-state actors, rather than to the correlation of forces.

Attempts in the 1990 s to define asymmetric warfare were mostly based on American scholarly writings. After the Chinese publication of Unrestricted Warfare in 2000, the US Army Strategic Studies Institute (SSI) commissioned a study to examine the concept of asymmetric warfare (Buffaloe 2006:9). The September 11, 2001 attack on America emphasised the fact that asymmetric approaches can no longer be considered secondary to conventional threats. In 2002, Steele (in Buffaloe 2006:10) called for a policy shift by stating that a new integrative paradigm was needed to face non-traditional threats and sources. In 2003, amidst several debates on asymmetry, Stephen Blank (Buffaloe 2006:11) wrote that the "term had become 
too many things to too many different people and that its amorphous nature detracted from its utility", because the term characterised everything from the threats planned to fighting such wars. However, Buffaloe (2006:17) proposed the following definition of asymmetric warfare:

Asymmetric warfare is population-centric non-traditional warfare waged between a militarily superior power and one or more inferior powers, which encompasses all the following aspects: evaluating and defeating asymmetric threat, conducting asymmetric operations, understanding cultural asymmetry and evaluating asymmetric cost.

Although this definition is supposedly universally applicable, it refers specifically to the current asymmetric warfare the US has been fighting in Iraq since 2003 (Buffaloe 2006:17). It is argued here that, since the definition lacks universal application, it cannot necessarily be applied to other countries, such as in Africa, where unconventional, intrastate wars (irregular conflicts) are occurring. The lack of universality of the definition raises questions as to the application of certain definitions in the African security environment. The author agrees with Grange (2000:2) regarding the notion of inapplicability by stating that high-tech warfare is largely ineffective against fourth-generation (guerrilla) adversaries. It is like playing "American football on a European soccer field" or in this case, in an African bush war.

Since the US focuses on expensive high-technological, low-casualty combat in asymmetric thinking, the viewpoint does not correspond with inexpensive, limited low-technological guerrilla strategies used in intrastate conflicts in Africa. Therefore, the premise of this article holds that African and Western asymmetric strategies are not synonymous since conventional high-tech precision weaponry is scarcely used in African unconventional, irregular situations, because African governments and their contenders mostly do not have access to expensive military equipment to defend themselves against non-state actors. Further, the weak or imploding state frequently does not hold superiority in large numbers against its contenders. The US, as a superior power with enormous resources, usually utilises highly trained conventional forces on a large scale against an asymmetric threat (Grange 2000:1), whereas African intrastate wars between ill-equipped and relatively small, poorly trained government defence forces and non-state actors are described as irregular warfare with few resources and limited means available in the conflict.

By 2007, the US military questioned problems associated with asymmetric warfare, such as why they would even consider using conventional forces in asymmetric situations (Bullock 2007:1). Bullock's contention was that 
unconventional warfare had to be met with unconventional strategies: "anything other than boots on the ground". Fewer troops could raid the recruiting camps and infiltrate the enemy infrastructure while seizing back the initiative by striking appropriate targets (Bullock 2007:2). These same unconventional strategies could be utilised by African defence forces, however, in weak and failed states the situation could be different. When attacking belligerents, African defence forces could find it difficult to successfully oppose guerrilla strategies used by non-state actors who target government and civilian institutions to seize initiative by raiding and plundering in order to survive and prolong the conflict.

\section{Characteristics of asymmetric warfare}

Conceptualising irregular, asymmetric warfare can also be done by contrasting it with conventional symmetric warfare, which focuses on the government, the military and the people. Irregular asymmetric warfare, however, focuses on the people (population-centric) and not the military. In both cases, the goal remains to influence governments (Plant 2008:5). In symmetric warfare, two powers have similar military power and resources and rely on tactics that are similar overall, differing only in detail and execution, while in asymmetric warfare the tactics and military power of forces are dissimilar. The more dissimilar the belligerents, the more difficult it is to anticipate their unconventional, asymmetric actions. According to Bowie et al. (2003:130), "analyses of future warfare cannot review all aspects of military strategy and operations" because they are dissimilar by nature and do not lend themselves to trend analyses.

McKenzie (2000:2) agrees with the viewpoint that asymmetric warfare refers to "unconventional approaches that avoid or undermine our strengths while exploiting our vulnerabilities", eg. Al Qaeda attacking the US. The capabilities of opposing forces in the struggle and attempts to exploit each other's characteristic weaknesses or deficiencies are such that the militarily disadvantaged, unconventional force emphasises its special advantages by exploiting the conventional (highly developed) enemy's particular weaknesses effectively. Nonstate actors (or sub-state actors) in Africa use unexpected means, like guerrilla hitand-run attacks on government troops to deal stunning blows to opponents that are more powerful but not necessarily armed with sophisticated or "high tech" equipment. This interaction involves strategies and tactics outside the bounds of conventional warfare and is waged in a changing and unpredictable manner. In such a case, the emphasis is more on the irregular nature of the conflict than its asymmetry.

Unconventional, irregular warfare favours indirect approaches to counteract the opponent's influence and will, because belligerents want to make the 
territory ungovernable, or at least untenable for the occupier/dominant force to move freely in the region. The purpose is to hit the opponent's deficiencies to turn the conflict into one's own favour. This way non-state actors will force the government to give them at least part of what they really want, i.e. scarce resources, a stake in the economy or political power. Such low-intensity strategies may not necessarily be militarised and have no quick-fix solutions (Grange 2000:4). Parties wage irregular warfare through social, political and economic strategies as well as disinformation through print and pirate radio stations as part of psychological warfare. It is necessary to win the "hearts and minds" of the population through information, disinformation and manipulation (Botha 2007:4). According to Plant (2008:5), irregular warfare focuses "on influence over the relevant populations"; this concurs with the definition by Buffaloe (2006:17), which refers to population-centric characteristics. Therefore, the belligerent, smaller force uses unconventional tactics in guerrilla warfare, such as hit-and-run, while relying on a friendly population providing assistance, supplies and necessary information. Belligerent forces in Africa usually operate in difficult and varied terrain, such as forested and mountainous regions (even semi-arid areas) providing cover and concealment, where the mobility of larger, conventional forces is restricted and where they can escape reprisal from larger, usually conventional government defence forces.

The concept of asymmetric warfare arguably could relate to the concept of "Fourth Generation Warfare", which refers to conflicts in which one of the parties in the conflict is not a state and where the state loses its monopoly to wage war against decentralized non-state actors not adhering to the rules of conventional warfare (Lind 2004: 13-14). This involves irregular or guerrilla warfare waged by non-state actors (or sub-state actors, micro territorial groups) motivated by ideology, revenge, lust for power, ethnicity, religion or some unifying bond (Corbin 2001:2). When practised outside the laws of war, irregular warfare is often pejoratively called "terrorism" (Botha,2007:3). Notable is that from the asymmetric warfare dictionary the elusive non-state actor is also labelled "terrorist". According to Grange (2000:3), terrorists and transnational criminal organisations have a completely different mindset, believing they are constantly at war. They use violence as a primary tool against democratic people worried about a threat to their way of life.

The new way of asymmetric warfare exhibited over the last decade against the US, for example the September 11, 2001 attack on New York also refers to international terrorism. This attack is not comparable with intrastate wars in Africa, because strategies and circumstances differ significantly in the manifestation of irregular conflicts in Africa (cf. Bowie et al 2003:130). There seems to be an important difference between the concept asymmetric warfare used and applied elsewhere when compared with the reality of irregular warfare in contemporary 
Africa. Opportunistic guerrilla strategies against local governments and civilians in Africa are different from expensive high technological, planned attacks against the US or what can be described as "transnational terrorism" against which a "war on terror" is waged. However, in both cases the underlying concept is a term originating from violent confrontations between two or more forces or belligerents, whose military strength, power and resources are mismatched. The main notion of irregular warfare in Africa is that the state's monopoly on violence is something of the past, and any understanding of African conflicts needs to take into account the history, specific ethnic cultures, politics, technology and irregular, unconventional tactics, unorthodox equipment and strategy used to offset the conventional superiority of opponents which may itself represent a weak or suspended state (Hugo 2009:105). The use of the term asymmetric warfare in the African context thus needs some qualification or broadening to include irregular guerrilla strategies. "Asymmetric" warfare in Africa is exemplified by non-state warfare between two forces rather than between formal militaries. This could be seen as a classic actionreaction-counteraction cycle. "Asymmetric" warfare here combines guerrilla tactics, civil disobedience, social, cultural and economic strategies, as well as disinformation to attack the opponent's political will directly in order to maximise influence (Jackson 2007:4).

Most African conflicts are waged by a mixture of groups such as non-state actors, state organisations, militaries and informal groups. Examples of the latter include "warlords", ethnic entrepreneurs - even pirates or smuggling networks. These groups range from organised revolutionary movements to local cells of global insurgency movements and even localised criminal gangs. The conflicts are primarily driven by economic motivations based on the greed model of Collier and Hoeffler (2002). The political history of the African continent focuses on militaries that have become politicised and involved in government, with little separation between the military and executive functions of government (Jackson 2007:6). This could be seen as one of the causes of an increase in intrastate conflict in Africa since the 1960s after independence from colonialism.

Groups in terms of the greed-model frequently fight the developing or failed state not because of a well defined ideology, but rather to gain control over, or access to scarce resources. On the African continent the difference between asymmetric and irregular needs to be kept in mind when intrastate conflict is at stake.

\section{African irregular intrastate conflict}

Intrastate conflicts, also called civil wars, have been more common during the $20^{\text {th }}$ century than interstate wars. War between African states has been a relative 
scarce phenomenon compared to civil conflicts. After independence from colonial powers in the 1960s, disputes over natural resources such as diamonds, gold and cobalt often led to armed conflict that evolved into guerrilla warfare. These wars were by-products of historic disputes kept hidden during the Cold War. When the ideological Cold War confrontation ended, they surfaced again (Eyal 2000:1). Therefore, the end of the Cold War in 1989 and the dawn of new international conflicts worldwide brought new challenges of unprecedented scope and complexity to Africa in the early 1990s. Consequently, the changing nature of international politics and subsequent conflicts, motivated by grievances and economic greed, led to an increase in irregular warfare, which if we want to term it asymmetric warfare needs some modification of the term asymmetric warfare.

Some of the most challenging conflicts currently in the world are in Africa, e.g. the Somali and Darfur crises and the protracted conflict in the DRC. The northern region of the DRC, Southern Sudan, Rwanda and Northern Uganda could be regarded as one conflict in view of open borders. In fact, these confrontations are a cluster of different conflicts. Border regions are central to African conflicts, since conflicts start in particular countries and mostly spill over at least one border. An important reason for this is the permeability of African state borders and the weakness of African states themselves (Cilliers 1999:138). However, almost all internal conflicts have regional dimensions since neighbouring countries involved themselves in the internal affairs of others and allowed their territory to be used by rebel groups. Alternatively, cross-border actions do take place, such as in Rwanda and the DRC, because most countries are simply incapable of controlling their borders (Cilliers 1999:139).

Border regions sustain conflicts by providing exit strategies for armed groups beyond the reach of conventional African security forces. In Central Africa, Zaire collapsed, and vast areas of the DRC effectively became lawless, while supporting many different groups of armed belligerents, as well as those in Sudan, Uganda, Rwanda and Burundi. According to the United States Institute for Peace (Docking 2001:2), the conflict in the DRC was the most protracted war in Africa since 1998. The conflict involved the armed forces of nine different states and approximately nine rebel groups. Most belligerents maintained power with machetewielding intimidation and took advantage of weak states for refuge. The discontent of the local population provided support, and once established, belligerents operated in and out of border areas with impunity (Grange 2000:3). Many border regions provided safe havens for belligerents as they moved around to wage irregular warfare among the local populations. 
In West Africa, safe havens are created along the Mano River countries of Liberia and Sierra Leone, as well as Guinea-Bissau and Côte d'Ivoire, providing shelter for insurgents, gangs, smugglers and syndicate networks. The Uganda-Kenya border also supports violence by giving cattle-rustlers the opportunity to cross the permeable border regions. The notion is that conflicts cannot be contained within national borders and have the potential to undermine regional peace, security and stability (Aboagye \& Bah 2005:xvi).

Collier and Hoeffler (2002) studied the reasons for and triggers of civil wars. Two contrasting motivations for civil wars were compared, namely greed and grievance. It was found that grievances as a motivation for civil war were mostly rare, because it was empirically proven by these authors that many civil wars were linked to the capture of natural resources. Greed of belligerents was the chief motivation. This relates to a conflict perspective where both parties do not have similar resources to utilise.

The link between the global nature of sought-after commodities, such as diamonds and oil, and the local nature of conflict is significant. For instance, resources played a significant part in prolonged conflict in Angola, Sierra Leone and the DRC in the latter part of the 20th century. Global trading networks engaging in illegal activities have become frequent and have given rise to trade in diamonds in Sierra Leone and Angola, uranium in Sudan, hardwoods in Liberia and human trafficking in Sudan and Liberia (Jackson 2007:7). These illegal networks are selffinanced and able to propagate war. According to Musah (2002:1), private military companies and local warlords are the principal actors in illegitimate resource appropriation in Africa. Non-state adversaries grow with the help of criminal financing and modern technology to suit their objectives. This is an important motivation for ongoing irregular warfare in Africa.

According to Jackson (2007:7), the continuation of war becomes an aim in itself to create conditions to profit from "grey trade" and for self-enrichment. Rebel groups gain control of specific resources and then use it to prolong the conflict, e.g. in Sierra Leone. In Angola, the rebels under Jonas Savimbi had control over oil and "blood" diamonds (initially also ivory), which prolonged the conflict for years. According to Jackson (2007:9), the prevalence of loot plays an important role in the motivation to continue violence. War and killing are means to loot property to achieve financial gain as a survival strategy to sustain rebel groups. In the absence of a formal pay system for belligerents, "loot is the chief method of payment for fighting" (Jackson 2007:10). These actions are consistent with the greed model.

Whatever the individual motivations of belligerents for entering into and prolong fighting, be it grievance or greed, the African intrastate conflicts mentioned 
below correlate with these motivations and characteristics of unconventional, asymmetric warfare and serve as examples of the utilisation of asymmetric warfare in African conflicts. It is not the intention of this article to give an extensive exposition of intrastate conflicts. Rather some examples of the various African asymmetric or irregular conflicts since the 1990s will be discussed. These are the conflicts in Liberia, Sierra Leone, the DRC, Rwanda, Burundi, Somali and Darfur in Sudan. According to Berdal (2005:2), the conflicts in Angola, Sierra Leone and the DRC were all shaped by the assumptions of the greed model, referring to the illegal extraction of minerals for sustaining forces.

\section{The conflict in Liberia}

In West Africa, the end of the Cold War coincided with the outbreak of civil war in Liberia, which lasted from 1989 until 1997. This conflict between former President Samuel Doe and rebel militias and their various splinter groups was the first intrastate conflict in Africa. It entailed considerable humanitarian crises; however, the international community paid little attention to this during the 1990s (Aboagye \& Bah 2005:xiii). In July 1997, Liberians went to the polls, but were bribed and intimidated by warlord and former President Charles Taylor's factions and militias who made false promises that the war would end if they were to vote for him. He prevented opposing candidates from campaigning for votes. Consequently, Liberia's transition from war to peace under Taylor was a complete failure. The country relapsed into another conflict in 2001 (Gberie 2005:62). In 2001, conflicts between rebel groups of Charles Taylor and Liberians United for Reconciliation and Democracy opposed to his rule escalated. Taylor fought for control of territory and adopted a policy of targeting unarmed civilians who were sexually violated, raped, tortured and killed on a regular basis (Jalloh \& Marong 2005:194). In August 2003, African troops under the auspices of the Economic Community of West African States (ECOWAS) deployed a Nigerian-led force with US support. Nigerian President Olusegun Obasanjo led an extensive African Union (AU) diplomatic effort to end the rule of Taylor, who agreed to step down and subsequently went into exile in Nigeria. The UN mission (UNMIL) took over in September 2003 and in November 2005, after 14 years of civil war, the new president, Ellen Johnson-Sirleaf, was elected in a free and fair election (Pan 2005:2).

\section{The conflict in Sierra Leone}

In Sierra Leone, civil war began on 23 March 1991 between the government and the Liberia-backed Sierra Leonean Revolutionary United Front (RUF), mercenary fighters and soldiers from Burkina Faso, who invaded Eastern Sierra Leone and the Mano River bridge linking Sierra Leone and Liberia (Ero 1999:62). Reports at the time suggested that Charles Taylor of Liberia had organised 
and armed the troops for the attack. He tapped into growing dissatisfaction of several dissident opposition groups to launch an attack in order to undermine the Sierra Leonean government under President Joseph Momoh to send troops to assist the ECOWAS Monitoring Group's (ECOMOG) forces to end the civil war in Liberia. Between March 1995 and January 1996, Nigerian troops under ECOMOG and the South African private security force, Executive Outcomes, defeated the RUF. Peace negotiations were ignored by the rebels and attempts to rebuild Sierra Leone were unsuccessful from the beginning (Ero 1999:63). Renewed fighting broke out and ECOMOG "found itself compromised in its ability to respond to the jungle warfare tactics" or asymmetric warfare of the rebels (Ero 1999:64). Over 3000 civilians died and many were abducted, intimidated or maimed. Several peace negotiations later in 1996 and 1997 still did not end the civil war, crippling Sierra Leone until the eventual signing of the Lomé Peace Agreement in July 1999 (Ero 1999:64). The United Nations (UN) peace mission, UNAMSIL, was established in October 1999 with a well-defined mission and clear goal to assist in the implementation of the agreement, after which democratic elections took place in May 2002. However, experts reported that low-level, unconventional, asymmetric fighting still continued (Pan 2005:2).

\section{The conflict in the Democratic Republic of the Congo}

The DRC with its vast areas rich in resources such as diamonds and gold, had suffered armed intervention since 1997 by a multitude of belligerents from nine other African states, which were all involved in the civil, asymmetric warfare (Pan 2005:2). After increased ethnic conflict between rival militias in the north-eastern Ituri district, a French-led intervention took place in June 1999. The Lusaka Ceasefire Agreement was signed a month later and then the UN peace mission, MONUC, was created to keep the peace. After January 2001, when Congolese President Laurent-Désiré Kabila was assassinated, his son, Joseph Kabila, took over and moved towards peace and reconciliation, leading to the withdrawal of the other African nations, who were committed to an agreement on political transition. After the civil war, MONUC took over in 2003 to monitor peace. However, in the last few years renewed asymmetric warfare has broken out in the Ituri and Kivu provinces, which are still presenting new challenges such as illegal trade and small arms smuggling in 2010. It was also proven that the UN troops from Pakistan and India had exploited their position of power to trade in gold with militias in exchange for weapons and ammunition to restart and prolong the conflict (Institute for Security Studies Briefing 2008). The question is whether this conduct is purely for economic reasons such as illegal "grey trade" or for ideological and political reasons as well. 


\section{The conflict in Rwanda}

In Rwanda in 1994, the genocide of Tutsis occurred at the hand of the majority Hutu. The causes of the genocide were mostly ethnic clashes over superiority and self-determination (grievance model). The Rwandan UN mission (UNAMIR) proved to be the greatest failure in terms of human rights abuses in our times. The UN stood by and watched while the 1994 genocide of Tutsis at the hand of the Hutu occurred. Lacking manpower and the necessary mandate to intervene to stop the mass murder, UNAMIR as a skeletal force at the time was, forced to act as a passive observer and unable to change the course of events (Bah 2005:27). The international community and the UN remained indifferent, instead of creating a well-defined mission and operational goal and plan, a secured source of funding, manpower or commitment and leadership to see the peace mission through. The UNAMIR forces watched the genocide unfold, apparently powerless to intervene, leaving thousands of innocent civilians at the mercy of the genocidal Rwandan army and their allies, the Interahamwe militia, consisting mostly of government-backed child soldiers. Calls by the UN commander, Lieutenant-General Roméo Dallaire (2004:backpage), for an expanded mandate and more forces to keep the peace fell on deaf ears. Over a period of 100 days, the genocide left 800000 Tutsis and moderate Hutu dead and thousands more injured, and caused countless people to become refugees and internally displaced persons.

\section{The conflict in Burundi}

Alike Rwanda, Burundi, the long-standing ethnic conflict between the Hutu majority and Tutsi minority engulfed the country. Burundi was seen as part of the spill-over effect of the DRC conflict, as well as the crisis affecting the Great Lakes region (Naidoo 2001:45). The Arusha Peace Accord for Burundi was signed in August 2000. It was mediated by former President Nelson Mandela. Under the auspices of the AU, 700 South African troops were sent in 2001 to protect $150 \mathrm{Hutu}$ politicians returning from exile to negotiate Burundi's transitional government (BuaNews (Tshwane) 2009). The South African intervention or protection force was seen as potentially risky, given that not all the fighting groups had accepted South Africa as neutral. A ceasefire was not yet in existence in Burundi during deployment and the mission was worrisome. The protection force had to use force to protect politicians, which was not in line with peacekeeping principles, supposed to be impartial and not using force. This led to the first-ever AU peacekeeping force intervening in violent conflicts between Hutu and Tutsi factions. Troops from Ethiopia and Mozambique deployed only partially, because of lack of funding. The UN mission (ONUB) took over the peacekeeping in June 2004 and consequently considered successful (Pan 2005:2). In August 2009, after eight years of 
peacekeeping, the South African contingent of peacekeepers withdrew from Burundi. The withdrawal signified an end to the long-standing conflict (BuaNews (Tshwane) 2009).

\section{The conflict in Somalia}

Somalia slid into factional conflict in 1991 after the repressive regime of President Siad Barre. It can be argued that this conflict was characterised more as irregular than asymmetric. Somalia collapsed into a state of chaos and civil war where regional aggressors chose to use their population as assets to be expended by starving them (McKenzie 2000:40). With lawlessness, banditry, mass starvation rife and no organised government at hand, humanitarian problems became serious. Muslim extremists and different warlords fought one another for the spoils, while policing along Somalia's coastline disappeared (Potgieter 2009:8). Since then, numerous UN-backed efforts to restore peace and stability have failed and so have many ceasefire agreements (Shabelle Media Network (Mogadishu) 2008).

The humanitarian intervention by the UN mission (UNISOM) in Somalia in 1992-1993 was generally considered as the first peacekeeping failure. This was the only time that US troops intervened in a war situation on the African continent. There was a well-defined objective, as they were only authorised to protect humanitarian aid deliveries to end starvation among Somalis, but according to McKenzie (2000:5), it was an example of the failure of an asymmetric approach at strategic level. Although the US force used helicopters for insertion and sophisticated weapons, the operation turned sour. The helicopter were unexpectedly shot down and the US troops ended up trapped in an urban maze where it was difficult to exploit technological advantages, while the enemy was willing to expend large numbers of human lives. This ended in a 24-hour fire-fight with armed warlord General Mohammed Farah Aideed in Mogadishu on 3 October 1993, resulting in the killing of 18 US Army rangers and hundreds of Somalis. Failure to know the enemy in an asymmetric war situation and to understand the power addiction of influential Somali warlords and deal effectively with political, social, economic and cultural aspects relevant to the situation had tragic, unintended consequences. This event concurs with the premise of this article that conventional high-tech precision weaponry cannot always be utilised successfully in African unconventional, irregular situations: Somali warlords waited patiently for the opportune moment to spring a surprise but lethal counterattack. This incident ended all Western and US peacekeeping participation in Africa. They withdrew in March 1994, sending only observers and specialists to the troubled spots in Africa since then (Anon n.d.). This is an example of how a tactical event can directly influence national policy and strategy, particularly when the US has no interest at stake (McKenzie 2000:5). 
Somalia is still plagued by renewed conflicts that started in 2006 between Muslim extremists and the Mogadishu government. Various mediation efforts failed as the Union of Islamic Courts seized Mogadishu and much of the south in June 2006. However, by the end of 2006 the region was seized again from the Islamists by forces loyal to the interim administration and also backed by Ethiopian troops (Potgieter 2009:9). By 2008, the AU had deployed approximately 2500 peacekeepers in Mogadishu, although it originally pledged 8000 troops. A Somali spokesperson, Jim'aile Mahmud Nur, requested the UN to give additional information about the deployment of UN peacekeepers because the peacekeepers had to be neutral in the Somali conflict and the civilian population must accept the peacekeeping troops. Information on their functions and eventual withdrawal was necessary, since they would replace the Ethiopian troops. The Somali request was also that UN peacekeepers should enforce a ceasefire in Mogadishu to ensure lasting peace (Shabelle Media Network (Mogadishu) 2008). This request for military might is, however, questionable because the underlying political cause of the conflict should be addressed first, as political problems require political solutions dependent on the characteristics of the native population. After 17 years of violence and anarchy, Somalia still needs a strong central government authority. In 2009, peacekeeping negotiations were still under way and piracy of foreign vessels irregular conflict - against the shorelines of Somalia continued owing to lack of government authority.

\section{The conflict in Sudan}

In Sudan, the root causes of the long-standing conflict stretching over three periods - 1955-1972, 1975-1982 and 1983 to date - refer to cultural, religious, historical, ethnic and political diversity between North and South Sudan. The south regards itself as African, mainly Christian, while the north regards itself as an economically more advanced Arabic, Muslim entity. The colonial history developed the two parts separately. The north was treated as part of the Middle Eastern world, whereas the south was part of the British East Africa territories (Yoh 2001:28). Several power struggles between different fighting groups led to protracted conflicts. Reconciliation between warlords was never achieved. In June 2004, the AU deployed an observer mission to the western Darfur region in Sudan to monitor continuing attacks by armed, government-backed militias against the southern Sudanese residents and civilians. The UN mission, established in March 2005 in Sudan (UNMIS), had a well-defined mission to liaise and coordinate with the AU mission. This mission was taken over by the UN (UNAMID) in June 2006, but the Sudanese government, led by President Omar Al-Bashir, refused to cooperate with the UN. 
In August 2006, the UN called for a 20000 -strong force to deploy to Darfur by October of that year to assist the AU. The UN already had a 10000 -strong force in Southern Sudan to maintain peace after the two-decade-long civil war. This new resolution would have resulted in the largest UN peacekeeping force in Sudan, but disagreements among $\mathrm{AU}, \mathrm{UN}$ and Sudanese representatives blocked its deployment. Only in June 2007, after four years of bloodshed and no peace to keep, the Sudanese representative finally agreed to the deployment of an international peacekeeping force (Patterson 2008:18). In October 2007, at least 10 AU soldiers were killed in Darfur when 1000 rebels from the Sudan Liberation Army unexpectedly attacked the peacekeepers' base outside the town of Haskanita. In January 2008, Sudanese government forces opened fire on peacekeepers, although they denied the attack was intentional (Evans-Pritchard, 2008). The crisis in Darfur, labelled by the UN as genocide, has revealed glaring weaknesses in the AU's ability to conduct its own peacekeeping operations, while the AU/UN mission in Sudan has been considered a failure by many experts (Pan 2005:3).

The reason for the failure was that the peacekeeping force was too small and its mandate too limited. The aim was for UNAMID to have 19555 military personnel, but only 13443 troops were deployed in July 2009 (African Union 2009). The problem was partly an issue of resources and of staying the duration of the mission. The mission was initially only intended "to monitor the situation and report cease-fire violations, but is not authorised to protect civilians from attacks by janjaweed, government-backed Arab militias" (Pan 2005:3). In the ungoverned border region between Western Sudan and Eastern Chad, the primary non-state belligerent is also the janjaweed militia, which is a group of armed gunmen who intermittently control the Darfur region of Western Sudan and who are responsible for the ongoing genocide (Plant 2008:7). The militia mostly comprise nomadic Sudanese fighters contesting with agrarian Sudanese for resources and land. Since Sudan has sovereignty, the international community could not intervene effectively and this led to an estimated 1,8 million refugees, while 1.6 million Darfurians fled to other regions of Sudan and crossed the border into Chad, causing the conflict to spill over into the neighbouring state. It was estimated in 2004 that 70000 displaced persons had died in the previous six months from malnutrition and disease (Plant 2008:7). Although international organisations tried to find effective ways to intervene against the stateless militias, it was difficult to end the human tragedy. The $\mathrm{AU}$, the Arab League and the UN had been unable to motivate action under the Genocide Convention (Plant 2008:7).

New peacekeeping demands in Sudan, Chad, Somalia and the Central African Republic required 30000 to 50000 more troops over the period June to December 2008. According to Patterson (2008:14), the current situation puts strain 
on the already exhausted international peacekeeping system that has seen a $600 \%$ increase in the number of peacekeepers since 1998. It is probable that the newly established African Standby Force will assist in peacekeeping missions in Africa as envisaged. Solving irregular or "Africa type asymmetric conflicts" will require unified international actions between governments and non-government organisations. However, unequal forces compete for political and economic power and supremacy in a "winner takes all" environment. It is the contention that peacekeeping cannot bring long-term security and stability if the basis for equitable participation in wealth appropriation is not established. This notion refers to a conflict perspective relating to power differentials between governments and belligerents fighting for equity and resources.

The abovementioned African conflicts see exponential growth of ungovernable areas, which provide fertile ground for irregular conflicts to flourish. According to the UN office in West Africa, slum areas are the norm for urban populations that are deprived of land ownership and basic sanitation and electricity. The youth of West Africa constitute $60 \%$ of the total population of about 270 million (Plant 2008:7). Most of them are unemployed and destitute. High percentages of youth, rapid urbanisation and declining resources are demographic factors that could be breeding grounds for future non-state operatives. This fact is related to the legacy of weak governance and permeable borders, leading to the probability of more irregular warfare emanating in the future. These reasons for such warfare correspond with the grievance and greed models mentioned earlier.

\section{Points for further discussion}

The current use of the term asymmetrical warfare sits uneasy in the African context as outlined above. The term irregular warfare seems to be more appropriate; alternatively, the concept of asymmetric warfare needs to be qualified and honed for use with reference to conflict phenomena on the continent. Motivations for asymmetric warfare as a refined and qualified concept specifically in the African context, are based on a combination of the grievance and greed models and correlate with the different intrastate conflicts promoting context bound asymmetric or irregular warfare in weak and failed African states:

- Democracy does not prevail in closed political systems, and non-state organisations do not recognise the current government, e.g. in Sudan.

- Weak governance in failed African states results in favourable conditions for belligerents to assume new attacks on government and the local population, e.g. in Liberia and the DRC. 
- Open, uncontrolled borders give belligerents free access to neighbouring states without being detected, e.g. in Burundi, Rwanda and the DRC.

- Ethnic groups clash over self-determination and superiority, while feelings of marginalisation led to genocide in the case of Rwanda's Hutu and Tutsi population in 1994, as well as ethnic conflict in Sudan and Somalia.

- Natural resources such as gold, diamonds, oil and uranium are always a cause of conflict because profitable "grey trade" is used by belligerents to fund and prolong the conflict, e.g. in Sierra Leone, Sudan and the DRC.

- Religious conflicts between Muslims and Christians are relevant in countries such as Somalia and Sudan.

- Long-standing conflict creates economic hardship for the local population as well as the belligerents. Smuggling and illegal trade occur frequently in war-torn countries where poverty is rife, e.g. in Somalia and Sudan.

These motivations for intrastate conflict explain the reasons for the utilisation of unconventional, irregular warfare as an expanded, qualified concept to understand modern African intrastate conflicts.

\section{Conclusion}

This article maintains that irregular warfare in Africa will be the mainstay of all contemporary and future intrastate conflicts in countries where democratic norms and values are not adhered to and where inherent contradictions exist in societies where people have unequal access to resources. The problem of the universality of the definition of asymmetric warfare relates to the customary US thinking of high-technological precision weaponry used in asymmetric warfare, while this is not the case in African intrastate conflicts where mostly lowtechnological guerrilla warfare is employed. Moreover the states that (has to) contain such conflicts are seldom technologically advanced, nor always in control of large scale, well disciplined, paid and equipped armies. The premise is that these different strategies cannot be compared, since US strategies are mostly incompatible with the clash of intrastate wars in Africa. For this reason, should one want to use the term asymmetric warfare in the context of Africa the term should be suitably expanded or at least qualified to specify and include different African low-intensity bush war strategies.

Although several UN and AU peace missions deployed in conflict-ridden Africa over the years, humanitarian actions have thus far not brought about the peace and security searched for, because long-term security and development cannot be achieved unless equitable participation in wealth and power is established in post- 
colonial states. This notion refers to a conflict perspective relating to power differentials between governments and belligerents fighting for resources. Democracy in African countries remains an ideal type, since many countries are still struggling for peace and stability, political freedom and good governance, while economic and social needs bringing order and stability to various African populations may still take years to accomplish.

\section{REFERENCES}

Aboagye, F. \& Bah, A.M.S. 2005. A tortuous road to peace. Brooklyn, Pretoria, Institute for Security Studies.

Aboagye, F. \& Rupiya, R.R. 2005. Enhancing post-conflict democratic governance through effective security sector reform in Liberia. In Aboagye, F. \& Bah, A.M.S. 2005. A tortuous road to peace. Brooklyn, Pretoria, Institute for Security Studies. 249-280.

African Union. 2009. Report of the Chairperson of the commission on the situation in Darfur. Peace and Security Council $198^{\text {th }}$ meeting. 21 July. PSC/PR/2(CXCVIII). Addis Ababa: 1-11.

Anon. Somalia. Small Wars Journal. n.d. Available at http://smallwarsjournal.com/reference/somalia.php. (Accessed 14.4.2009).

Bah, A.M.S. 2005. The intervention dilemma: the dynamics of civilian protection in the post-Cold War era. In Aboagye, F. \& Bah, A.M.S. 2005. A tortuous road to peace. Brooklyn, Pretoria, Institute for Security Studies: 21-49.

Berdal, M. 2005. Beyond greed and grievance - and not too soon. A review essay. Review of International Studies, 31: 687-698. British International Studies Association.

Botha, A. 2007. Relationship between Africa and International Terrorism: Causes and Linkages. Paper presented at the Conference on Southern African and International Terrorism. Brenthurst Foundation, Tswalu, 25-27 January 2007.

Bowie, C.J., Haffa, R.P. \& Mullins, R.E. 2003. Trends in Future Warfare. Joint Forces Quarterly. Issue 35, Summer 2003: 129-133.

Buffaloe, D.L. 2006. Defining asymmetric warfare. A National Security Affairs Paper, No. 58. September. Arlington, Virginia. Institute of Land Warfare, Association of the United States Army. 
Bullock, M. 2007. Unconventional thinking. Armed Forces Journal. NewsBank: Armed Services and Government News. 1 January. Available at http://infoweb.newsbank.com/iw-search (Accessed 30/3/2010).

BuaNews (Tshwane). Burundi: SA troops to be withdrawn from country. All Africa.com. 2009. Available at http://allafrica.com/stories/200907301003.html. (Accessed 12.8.2009).

Cilliers, J. 1999. Regional African peacekeeping capacity - mythical construct or essential tool? In Cilliers, J. \& Mills, G. 1999 (ed). From peacekeeping to managing complex emergencies: peace support missions in Africa. ISS: Natal Witness: 133-152.

Collier, P. \& Hoeffler, A. 2002. Greed and Grievance in Civil War. World Bank publication. CSAE WPS/2002-01. March 2002.

Corbin, M. 2001. Reshaping the military for asymmetric warfare. Terrorism project, October. Centre for Defense Information. Available at http://www.cdi.org/terrorism/asymmetric.cfm (Accessed 16.10.09)

Dallaire, R. 2004. Shake hands with the devil - the failure of humanity in Rwanda. Ottawa: Arrow Books.

Docking, T. 2001. Peacekeeping in Africa. Special report no 66. Part one. 13 February. United States Institute of Peace. Available at www.usip.org/resources/peacekeeping-africa (Accessed 19.5.2010).

Ero, C. 1999. The future of ECOMOG in West Africa. In Cilliers, J. \& Mills, G. 1999 (eds). From peacekeeping to managing complex emergencies: peace support missions in Africa. ISS: Natal Witness: 55-74.

Evans-Pritchard, B. 2008. Sudan: Weakness exposed in Darfur peacekeeping force. Available at http://allafrica.com/stories/200801250005.html (Accessed 12.8.2009).

Eyal, J. 2000. Africa's peacekeeping problem. Available at http://news.bbc.co.uk/1/hi/world/africa/743249.stm. (Accessed 5.7.2007).

Filatova, I. 2000. Democracy versus the state: The African dilemma. In Consolidation of democracy in Africa: A view from the south, ed. H. Solomon and I. Liebenberg. Aldershot: Ashgate Publishers: 11-20.

Gberie, L. 2005. Liberia's war and peace process: A historical overview. In Aboagye, F. \& Bah, A.M.S. 2005. A tortuous road to peace. Brooklyn, Pretoria, Institute for Security Studies: 51-71. 
Grange, D.L. 2000. Asymmetric Warfare: Old method, new concern. National Strategy Forum Review. Winter 2000: 1-5.

Hugo, F. 2009. Asymmetrical War and terror at sea: 2010 scenarios. In Potgieter, T. \& Pommerin, R. (eds). Maritime Security. Centre for Military Studies. Stellenbosch University: 103-111.

Institute for Security Studies Briefing. Events: 2008. The role of UN peacekeepers in re-arming rebel groups in the DRC. 18 August. Presented by the Organised Crime and Money Laundering Programme, ISS Cape Town.

Jackson, P. 2007. Are Africa's Wars part of a Fourth Generation of Warfare? Contemporary Security Policy. 28(2): 267-285.

Jalloh C. \& Marong, A. 2005. Ending impunity: the case of war crimes trials in Liberia. In Aboagye, F. \& Bah, A.M.S. 2005. A tortuous road to peace. Brooklyn, Pretoria, Institute for Security Studies: 191-228.

Lind, WS. 2004. Understanding Fourth Generation War. Military Review Sep-Oct: 12-16.

Mack, A.J.R. 1975. Why big nations lose small wars: The politics of Asymmetric Conflict. World Politics, 27(2): 175-200.

McKenzie, K. F. 2000. The Revenge of the Melians: Asymmetric Threats and the next QDR. McNair Paper 62, Institute for National Strategic Studies, National Defence University.

Musah, A. 2002. Privatization of Security, Arms Proliferation and the process of State collapse in Africa. Development and Change, 33(5): 911-933.

Naidoo, S. 2001. Challenges for Burundi's transitional government. Conflict Trends., 4/2001: 42-45.

Pan, E. 2005. Q\&A: African peacekeeping operations. New York Times International. $\quad 7 \quad$ December. Available at http://www.nytimes.com/cfr/international/slot3_120705.html?_r=1. (Accessed 10.3.2009).

Patterson. P. 2008. Darfur and peacekeeping operations in Africa. Military Review. July-August: 14-23.

Plant, J.T. 2008. Asymmetric Warfare: slogan or reality? Defence \& Strategy 8(1): $5-15$. 
Scientia Militaria, South African Journal of Military Studies, Vol 38, Nr 1, 2010. doi: 10.5787/38-1-79

Potgieter, T. 2009. When maritime security is absent. In Potgieter, T. \& Pommerin, R. (eds). Maritime Security. Centre for Military Studies. Stellenbosch University. 5-22.

Shabelle Media Network (Mogadishu). Somalia: "Details on UN peacekeeping mission is essential" Elder said. All Africa. com. 2008. Available at http://allafrica.com/stories/200806060750.html. (Accessed 12.8.2009).

Yoh, J.G.N. 2001. The dynamics of war and peace in Sudan. Conflict Trends 4: 2837. 